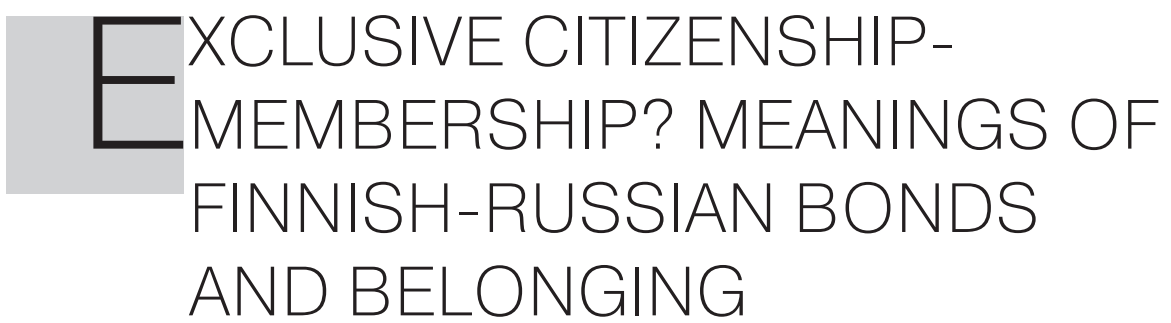

\title{
Teemu Oivo
}

Teemu Oivo, Karelian Institute, University of Eastern Finland. Address for correspondence: University of Eastern Finland, PL 111, Joensuu, 80101, Finland. teemu.oivo@uef.fi.

Research for this article was conducted with funding from the Strategic Research Council at the Academy of Finland under grants nos. 303480 and 303529.

\begin{abstract}
Besides defining the juridical relationship between individuals and a state, citizenship holds informal importance of belonging and empowerment in social environment. Perceptions of a "good citizen" reflect normative social and political construction of a society, which is often simultaneously influenced by human rights, migration, security, geopolitics, and nation-building. Initiatives to renegotiate the previously liberal Finnish citizenship became topical in the country's public discussions after changes in European security discourse in 2014. In early 2017 Finnish national broadcast agency, Yle, reported that Finnish-Russian dual citizens were covertly excluded from holding strategic military positions. Through the analysis of media presentations of these news and spontaneous discussions stimulated by them in an online forum of Finland's Russian speakers, this article examines citizenship as a discursive membership in Finnishness and Russianness. Ways of claiming, identifying, validating, and challenging "proper" citizenship have differed clearly in the discourses presented in Finnish national media and in online Russian-language discussions. Journalists and the defense minister, who was a key figure in the media discussions, presented citizenship as a flexible instrument of international security politics. The online discussions spawned debates about the possibilities of inclusion through integrating into and acclimating to Finnish social environment. The most alienating discourse in the online discussions entailed a belief that documented family history is essential for inclusion to citizenship-membership.
\end{abstract}

Keywords: National Identification; Citizenship; Online Discussions; Discursive Nationality; Transnationality

In early 2017 Finnish national broadcast agency Yle reported on discrimination against Finnish-Russian dual citizens in the defense forces. The defense minister responded that national security required changes to legislation to limit the recruitment of dual citizens in strategic positions in the defense forces (Yle News 2017a). The public discussion that followed touched on the idea of Finnishness, prejudice against Russians, immigration, and questions of the national security and loyalty. Later that year the Ministry of the Interior highlighted the dual citizenship issue as "the only widely discussed topic in the media related to immigration but not directly 
linked to refugees or asylum seekers" (2017:30). Eventually, the Finnish parliament passed amendments to exclude officer candidates with citizenship from or other ties to countries that "may cause a security threat" (Eduskunta.fi 2019). In the mid2010s several other states introduced new security regulations targeting dual citizenship. For example, states like Canada, Denmark, and Kazakhstan use revocation of citizenship as a national security instrument (Van Waas and Jaghai 2018; Midtbøen 2019; Oivo and Davydova-Minguet 2019).

It is challenging to fully comprehend the complex social significance of citizenship, which majority of people ordinarily enjoy from birth. Generally, citizenship concerns several fundamental ideological, democratic, political, legal, and social questions. Scholars in social sciences highlight the meaning of citizenship as a membership, a formal affiliation with a state (polity) and more informal bond to a society or a nation (Faist 2007; Blatter 2011). Formal and informal "genuine link" criteria for citizenship provide an interesting perspective on the hegemonic nationstate discourses suggesting people's belong to certain places and groups, which contradicts the social reality of people with transnational affiliations (see Yuval-Davis 2006; Bauböck 2019). This article focuses on informal dimensions of citizenship as discursive membership, which I refer to as citizenship-membership, engaging with scholarship on Russianness in transnational subjectivities, identification, and stigma (e.g., Neumann 1999; Davydova 2009; Oivo 2017). I analyze how discourses of citizenship-membership constructed problematization of affiliated belonging in an online discussion forum of Finland's Russian speakers following the presentation of dual citizenship as a security issue in the Finnish national news media in early 2017.

By discourses, I refer to networks of effective knowledge (i.e., ideas, beliefs, and perceptions embedding truth authority) manifested in formations of interrelated and rule-based statements about social constructions, such as citizenship (see Keller 2012). Formal and informal representations of dual citizenship depend on discourses of citizenship-membership, because they either enable its imagination within a "proper" membership or rule it out as a deviation. For the participants of the online forum discussion that is the focus of this study, discourses compose productive and restrictive knowledge about how to make convincing arguments and communicate effectively. Notably salient is the knowledge about the (invisible) audience and about the medium's technological properties. The positionality of these participants to build, maintain, and challenge popular perceptions about citizenship-membership in Finland is significantly limited compared to, for example, journalists, officials, and politicians with recognized status and access to national mass media (see Seppänen and Väliverronen 2012). News reports that set off the online discussions that I examine here include statements from journalists and the country's defense minister, both of which, despite the differences of their positions, were featured in an influential Finnish news media Yle.

The issues related to social belonging of people with immigrant background in Finland are often studied from perspectives of integration into society and culture. Experts in this field recommend inclusion of immigrants into the discussion about the desirable norms of integration and belonging (e.g., Heino 2018:25, 75). Accord- 
ingly, I analyze discursive representations of (transnational) Finnish and Russian membership(s) in discussions that Russian speakers living in Finland have in an online forum. Arguably, this forum is a public arena where meanings of belonging are discussed among people who have bonds simultaneously to Finnish and Russian societies and are positioned in both discursive fields.

Whereas my approach seeks to expand views on formal and state security meanings embedded in citizenship with its more informal dimensions, the specific context of dual citizenship in the military strongly influences the perspectives on citizenship-membership in online discussions. They highlighted controversial and difficult questions about transnational (non)belonging and whether citizenship should entail obligations and commitment to make "patriotic" sacrifices in hypothetical situations of extreme crises. While questions of threat usually provide impetus for people to question and articulate their identities (Yuval-Davis 2006), many people may see posing questions in such a way as too artificial, antagonistic, unpleasant, or counterproductive to think about. For example, liberal perception of citizenship would rather emphasize the obligations of a state to secure individual rights and citizens' autonomous subjectivity with minimalist commitments and obligations towards the state or a community (e.g., Blatter 2011). Hence, the existing research provides only a limited perspective on citizenship as membership.

In what follows, I first present the main analytical concept for the current study, citizenship as membership, within a broader framework of citizenship studies and transnational affiliations. For background, I review the Finnish and Finnish-Russian contexts in defining citizenship-membership before presenting my research method and data. My empirical analysis starts with the news reports about discrimination against dual citizens composed of intertwined discussions between Yle journalists and Finnish defense minister in the media. Next, in the primary analysis section, I examine an online discussion in a Russian-speaking forum to explore how these news reports were interpreted in the framework of Finnish-Russian citizenship-membership. The final section of the article brings the empirical and theoretical discussions together. In this article, I follow the terminology used in my data and much of the relevant literature when I refer to "dual citizenship" and "dual citizen(s)" even if there are more than two citizenships in question.

\section{CONVERGING AND DIVERGING CITIZENSHIP-MEMBERSHIP}

"Citizenship in a nation-state is inevitably bound up with nationhood and national identity, membership in the state with membership in the nation. Proposals to redefine legal criteria for citizenship raise significant and ideologically charged questions of nationhood and belonging" (Brubaker 1992:182).

As citizenship signifies individual's juridical, political, and social membership in a state, nation, and society, dynamics of citizenship provide an interesting subject for social research. Thomas Faist (2007:2-3) lists equality of political freedom, rights and obligations, and collective identity as conceptually defining elements of citizenship. Transnationally affiliated people especially may see that their citizenship signi- 
fies belonging to a society and polity rather than to a nation. Nevertheless, discourses of nationhood and citizenship are strongly intertwined, often converging and diverging along similar practices and principles of membership. This is a salient meaning of citizenship-membership.

A notion of "nation" controls an ordinary but meaningful identity vocabulary legitimizing political power, belonging, ownership, and social justice (see, e.g., Yuval-Davis 2006; Miller 2010). Benedict Anderson (1983) famously linked the proliferation of nationally dominated print capitalism with the emergence of nations as sovereign, solidary, and limited imagined communities in the nineteenth century. Over the recent decades the proliferation of mobile information and computer technologies has created new spaces for the production and imagining of transnational identities and communities (e.g., Georgiou and Silverstone 2007; Floridi 2015). Myria Georgiou (2013) argues that systems of citizenship and belonging should be critically revisited, as communications technology increasingly deterritorializes and renegotiates communities. In this regard Faist (2007:19) argues that dual citizenship strengthens multiple ties to a locality, to a region, and to transnational and international institutions and networks, while weakening the significance of national membership.

Citizenship has developed alongside military and security institutions. While the concept of citizenship stems from the classical antiquity, contemporary citizenship is strongly connected to the Westphalian norms that assign individuals and populations to states (Bauböck 2019). In accordance with popular sovereignty, the legitimacy of a state's authority is based on consent of its subjects, that is, sovereign citizens, but constitutions of several countries permit overriding this consent in a state of emergency. In a conflict between state sovereignty and individual rights, the norms of a modern nation-state are often opposed to dual citizenship. The inclusivity of citizenship rights varies over time and from state to state, because citizenship norms are connected with vast national, political, ideological, and global level developments. Generally, decolonization, changing state borders, increased mobility of peoples and assets, migrants integration policies, (neo) liberalism, universalist human rights, gender equality, and a smaller role for mass armies in states' military doctrines were factors that contributed to the growing acceptance of dual citizenship in the late twentieth century (Faist 2007; Triadafilopoulos 2007).

People may value their citizenship only instrumentally, but it can also embed sentimental value. The emotional affection is an informal but significant dimension of citizenship-membership, which contains norms related to belonging, love, solidarity, allegiance, ontological security, and readiness to make personal sacrifices for the community (see Anderson 1983; Kinnvall 2004; Yuval-Davis 2006). The contextual meaning of these concepts may vary significantly, and there are several more mundane ways of being, doing, experiencing, and understanding citizenship. For example, the vernacular concept of "good citizenship" can encompass support networks, civil society activities, voluntary communal work, and social trust (e.g., Atkins and Hart 2003; Goode 2016; Heino 2018). Rather than strictly defining each informal factor of citizenship-membership, in this article I examine them as functional ideas 
and beliefs that are often interconnected and contested by people who deliberate about them. The next section reviews relevant background for the current study of citizenship-membership through juridical, social, and historical contexts regarding citizenship(-membership) and Russian speakers in Finland. In the subsequent two sections I introduce my empirical material and research methods based on this background.

\section{EXPANDED AND LIMITED MEMBERSHIP}

In November 2017 the Finnish parliament passed amendments to the State Civil Servants Act (948/2017), the Security Clearance Act (949/2017), the Act on National Defense University (950/2017), the Act on the Governance of the Border Guard (951/2017), and the Act on the Police University College (952/2017). The amendments came into effect in 2018; they provide recruiters with more legal instruments to investigate foreign affiliations of candidates looking to become state officials (Valtiovarainministeriö 2017). Not happy with the extent of the amendments, Defense Minister Jussi Niinistö started to publically lobby for a complete ban on employment of dual citizens not only in the defense forces but also in the border guard (which is managed by the Ministry of Interior) (Yle News 2018). In the spring of 2019 the Finnish parliament amended the qualification requirements for the National Defense University, the border guard, and defense forces, disqualifying applicants with another citizenship or other affiliations with a foreign state that may pose a security threat (Eduskunta.fi 2019). These developments followed a long discussion about the terms and meanings of Finnish citizenship-membership and their compatibility with Russianness.

Finnish citizenship legislation complies with the norms of the European Union. Human rights and the rights of permanent residents (denizens) make up most of the individual's legal status in Finland. Citizens' legal obligations to the state include paying taxes, having a name, finishing compulsory education, and participating in national defense. Citizen rights include political rights, spatial rights (mobility and residence), and physical, diplomatic, and social security (Husa and Pohjalainen 2008). Finnish naturalization requirements include authentication of identity, a valid economic and legal record, proficiency in an official language (Finnish or Swedish), and a sufficiently long period of residency (Finnish Immigration Service n.d.).

In the contemporary European context Finland is considered an ethnically homogeneous state, partially as a result of its restrictive immigration policy during the Cold War (Forsander and Ekholm 2001:84). At that time, Finnish citizenship was constructed as an unquestionable and unitary membership that people were born and raised into. Policy makers believed that minimizing differences among citizenship holders would improve governance, security, and equality (Ronkainen 2006:244). Finland's immigration policy gradually turned more liberal and sought to attract immigrants after the fall of the Soviet Union in 1991, while the country became a EU member in 1995 and adopted the European Convention on Nationality in 1997. The new Nationality Act (359/2003), passed in 2003, removed the single citizenship limitation. Whereas some countries determine their dual citizenship policies based on 
bilateral agreements, Finland's Nationality Act applies to citizenships of any country, including Russia. Despite following the liberal trend in the EU and demonstrating a willingness to improve its attractiveness to immigrants, the reforms maintained ethnic elements of Finnish citizenship. One of their goals was to reengage with Finnish expatriates and facilitate their return to the "home" state (Ronkainen 2006:244248; Davydova 2009).

Previous research underlines the ambiguity of the significance of the membership aspect of citizenship in Finland. Mari-Liis Jakobson (2017) studied what citizenship meant to Estonian immigrants in Finland. Jakobson's interviewees who had made the difficult decision to renounce their Estonian citizenship in order to live and work in Finland as naturalized citizens valued their Finnish citizenship higher than those who no longer faced this decision after Estonia's entry into the EU in 2004. In the Soviet Union, the state dictated the meaning of citizenship, which was primarily about societal privileges and restrictions. Consequently, being a good citizen meant that one abided by the law and refrained from deliberative political participation and activism. Jakobson recognized this Soviet legacy in her interviewees, who associated good citizenship with respect for the law and only tenuously with the civic virtues of public and political engagement. Contemporary transnationalism, on the other hand, impels the interviewees' to associate citizenship with forward-looking post-national belonging.

Previous research suggests that, despite experiences of negative prejudice, Finnish-Russian dual citizens value their citizenships more than holders of other EU citizenships, for whom a second passport does not provide practical benefits. More generally, surveys and interviews of Finland's dual citizens highlight that they feel affection towards both their states of residence and "home" states. Studies of dual citizens aged 16 to 26 show that respondents are reluctant to compare and rank their citizenships, but long-term residency tends to increase their emotional affection to Finland (Ronkainen 2009, 2011). According to another study, immigrants often have a perception that Finnish population does not consider citizenship as an important signifier of societal belonging, which projects back on their own evaluation of their naturalized citizenship. A relevant comparative survey conducted among immigrants in 14 Western states found that Finnish citizenship was considered to entail least national belonging to its bearers (Simonsen 2017:9). Similarly, interview studies with Ingrian Finns who moved to Finland from Russia as (ethnic) repatriates after 1990 suggest that for the Finnish majority the language and ancestry are important markers of "Finnishness," making it very difficult for immigrants to adapt (Varjonen, Arnold, and Jasinskaja-Lahti 2013; Mähönen et al. 2015).

Public discussion of the Finnish-Russian dual membership emerged after the Finnish government in August 2014 launched an investigation into the dual citizenship policies in Finland and states close to it (Yle News 2014b). This was five months after Russia organized the annexation referendum in Crimea and in the same month that Russia started to penalize its citizens for failing to register their naturalized foreign citizenships (Vasutin 2014). At the time, Finnish officials downplayed the relevance of Russia to the initiative to reform the legislation concerning dual citi- 
zenship. However, several Finnish journalists concluded that the initiative did stem from recent events related to Russia, its newly instituted compatriot policies, and a growing share of Russian citizens among Finland's dual citizens (e.g., Mentula and Teivanen 2014; Yle Novosti 2017). According to the 2016 statistics, among 104,997 Finnish dual citizens living in Finland, 27,456 were Russian nationals, which is approximately four times larger than the second largest group, the Swedish (they are followed by much smaller groups of Somalian, Estonian, and US citizens) (Varjonen, Zamiatin, and Rinas 2017:30).

While Finnish-Russian dual citizens may travel between their neighboring homelands easier than most other dual citizens living in Finland, several of them have expressed the feeling of being a foreigner and an outsider in both states. In Russia, the growing distrust towards foreign countries has gradually extended to Russian citizens with affiliations abroad, crystallizing into social pressure such as accusations of treachery and enactment of juridical regulations against such individuals. However, there are simultaneous policies promoting attractiveness of Russia for compatriots abroad (Oivo and Davydova-Minguet 2019; see also Lohr 2012). In Finland, Russian-speaking residents and Finnish-Russian dual citizens have faced prejudices and ethnic stereotypes - such as being devious, violent, and drunken barbarianssimilar to those that some Finns have of Russians in general (Ronkainen 2009:106107; Varjonen et al. 2013; Heino 2018:72; Krivonos 2019).

The people who in Finland are perceived and labeled as Russians have diverse backgrounds, which is why statistical data, like citizenship status, is insufficient to define this group. While many younger people with a Russian or Soviet family background were born in Finland, in everyday interactions they may get associated with immigration and Russianness. Arguably, language is the most common denominator for people regarded as Russians in Finland. Finland's census data indicates that between 1990 and 2016 the number of Russian speakers grew from 3,884 to 75,444, making them the biggest linguistic minority in the country without an official status for their language (Varjonen et al. 2017). In the online Russian-language forums related to Finland that I have studied, posts are most often addressed to "Russian speakers" (russkogovoriashchie or russkoiazychnye). Comments to posts concerning ethnic Russianness (russkie) note that many of the discussants are not Russians or from Russia. Nevertheless, they acknowledged that this is how they are often labeled in Finland.

Finland's Russian speakers have often voiced concern over their alienating portrayal in the Finnish media and expressed a wish to be included in the Finnish media and public discussion not as representatives of the "Russian community" but as individuals. Interviews with Finland's Russian speakers illuminate how after 2014 many have felt a need to readjust their media use and social relations as an everyday strategic response to international tensions (Davydova-Minguet et al. 2016). In 2018 a group of them petitioned a newspaper for a public apology for pairing Finnish and Russian passports in an illustration to a news article about a bill to enable revocation of Finnish citizenship from dual citizens who commit a felony (Schwartz, Kriuchkova, and Nesterovich 2018). However, scholarship suggests that the Finnish 
media relatively rarely portray Russian speakers in Finland and hardly promote direct prejudices towards Russians. Nevertheless, these rare media representations tend to reproduce Russians' otherness, an overall negative view of Russia as a country, and the memory of Russia as Finland's enemy during World War II (e.g., Pietiläinen 2016; Oivo 2017).

\section{ONLINE DISCUSSIONS AS DATA}

The Russian-language media in Finland today offer limited possibilities for extensive in-group discussions (Davydova-Minguet et al. 2016:22-28). Hence, there are few alternatives to archives of internet discussions for a study of autonomous and public discussions among Finland's Russian speakers. Connected with information and communication technology (ICT), social media is one of the most talked about contemporary forms of globalization. The possibilities that social media provide challenge modern ways of comprehending the world, from spatiality and temporality to the existential questions (Floridi 2015). For example, the use of transnational media intrinsically challenges state-centrism and makes it easier to imagine the mediated communities, when their members are in instant interactions with each other (Georgiou and Silverstone 2007; Kissau and Hunger 2010). Due to the proliferation of various ICTs, evaluating the situated circumstances where people perform their online activities is increasingly difficult. Georgiou (2013:96) suggests that researchers do not make far-stretched assumptions about what the contemporary media environments of minorities are like, but focus on their practices and the meanings they give to new communication technologies.

Online forums of Finland's Russian speakers differ most notably in the ways their participants address each other rather than in their common points of reference. Several of the most popular social media groups among Finland's Russian speakers are on Facebook, whereas notably fewer of them are on VKontakte, which is a Russian equivalent of Facebook. I have chosen to examine Russian.fi due to its openness. Many groups of Finland's Russian speakers, especially those on Facebook, require joining them in order to read their discussions. Since these discussions are more closed, their use in research would be ethically more problematic than with Russian.fi. Established in 2002, Russian.fi is the oldest and one of the most popular Russian-language websites about life in Finland. The portal is a traditional webbased forum, mainly made up of discussion threads. Despite having a rather old interface, Russian.fi fits the basic definition of social media. People can share their self-produced content, quote, "like," and "dislike" each other's posts, most of which are in a textual form. Trending discussions are displayed on the front page. In addition to being a source of news, the forum attracts many users who search for information and opportunities to socialize.

One of the shareholders and administrators of Russian.fi highlighted that the fairly large number of the forum's registered users (approximately 35,000 in 2016) is not reflective of the number of people regularly participating in the discussions. In her estimation, no more than 2,000 of them participate in creating content, and majority of them simply ask practical questions (Davydova-Minguet et al. 2016). On the 
other hand, researchers like Olga Davydova-Minguet have embraced the forum as a place where people can discuss issues important to Finland's Russian speakers, give practical advices, created a sense of community, and form offline connections (Davydova-Minguet et al. 2016:77-79). The group of active forum participants has qualities of what Robert V. Kozinets (2012:9-10) characterizes as an online community. The forum's content reveals human affection among its users and the fact that the discussions among them have continued for a long time. Regular users recognize each other's profiles and refer to information that they learned from each other in earlier threads. Regular users even organize gatherings to socialize offline. Despite occasional arguments and even slander, many messages about everyday life grievances, hopes, and personal stories exhibit a certain sense of trust and togetherness, arguably stemming from the forum. These sentiments strengthen the sense of meaningfulness of social interactions on Russian.fi. Previous research indicates that sharing experiences in online communities with others with similar stigmatized status increase members' self-acceptance and decrease experiences of social isolation (Kozinets 2012:28).

Information security and issues of online privacy attracted a lot of media attention after Edward Snowden's revelations in 2013 about large-scale surveillance conducted by American intelligence services. Furthermore, issues of surveillance, visibility, and privacy on the internet have become a visible part of the popular media landscape in Finland. In the dual citizenship discussion thread on Russian.fi, on which this article focuses, there was a comment reminding the participants that the Finnish authorities, or Finns in general, might be "lurking" on the forum and get a bad impression of Russian speakers on the basis of some of the comments. Generally, internet users do not always know who can access, read, and own their posts. Moreover, the pseudonyms used on the forum do not provide complete privacy protection. Hence, I anonymized the identities of the forum's participants when quoting from their posts.

While I generally followed online forums of Finland's Russian speakers to become familiar with the context and relevant issues, in this article I focus on the first 180 messages from a Russian.fi thread established to discuss a news article about the defense forces' imposition of limitations on dual citizens (Yle Novosti 2017). These messages constitute the first three pages of the thread and were written during the first 18 hours by individuals with 42 different aliases and included only one nonregistered visitor. The discussion continued for eight days, but the early discussion features spontaneous reactions and expectations related to preexisting knowledge. After my initial reading through this archived online discussion, I saved its first 180 messages on my computer before coding messages and subdiscussions by topic.

Many discover the Russian.fi forum for the first time when, using search engines, they are looking for answers to everyday questions. Most daily visitors do not participate in discussions by posting, but half of them visit regularly. Roughly 60 percent of the Russian.fi users reside in Finland, 25 percent in Russia, and most of the remaining ones are in the states of the former Soviet Union. Following the escalation of the conflict between Russian and Ukraine in 2014, Russian.fi tightened its mod- 
eration policy in political topics to prevent provocations, particularly from new or nonregistered visitors (Davydova-Minguet 2017:13).

This study does not seek to make generalizations about all Russian speakers in Finland based on Russian.fi, but the discussions that it analyzes signify social knowledge (common ground) that have relevance beyond personal or in-group perceptions. It is possible to only roughly estimate the Russian.fi users' demographics. However, it is notable that the topics often include questions that are particularly relevant to people for whom their experiences in Finland are rather new. According to the forum statistics from March 2019, most of its threads were initiated in "juridical questions," "everyday life and family," and "work, education, and studies" sections of the forum. Most messages were written in sections "events and facts," "off topic," and "everyday life and family." These topics appeared as popular interests in several relevant discussion groups in Facebook as well.

Generally, the messages in the Russian.fi thread analyzed in this article were addressed to the entire imagined audience of the forum, that is, Russian speakers living in Finland, and not to individual active discussants or the people who are interested in the current topic from an outsider's perspective. Moreover, previous research has noted that while the internet can help social interactions to overcome physical distances, geographically related topics connect people in online discussions (Kissau and Hunger 2010). Overall, discussions on Russian.fi do not provide a statistically generalizable perspective on Finland's Russian speakers. Yet, as a place where they conduct meaningful discussions and reflect on their self-understanding and knowledge, it is arguably the most representative platform of this heterogeneous group.

\section{NETNOGRAPHY AND DISCOURSE}

I have applied Kozinets's (2012) netnographic approach to familiarize with, define, collect, and conduct initial analysis of the data from the forum's discussions. Proper netnography seeks to gain insight from online communities by establishing an insider perspective through researcher's own active participation. Alternatively, researcher's position can be observational and unobtrusive when the focus is on a social phenomenon instead of a specific online community or medium. This unobtrusive positionality provides autonomy for informants to decide how to define, address, and conduct their discussions.

People's online and offline identities and ways of self-representation do not necessarily correspond to each other, and their claims are often difficult to verify. $0 \mathrm{n}$ Russian.fi, discussion participants often demonstrated their online media literacy by questioning suspicious self-portrayals of participants. For my analysis, these suspicions of experienced forum participants exemplify knowledge of what is and is not considered normal self-presentation in a specific social context. I view online communications as a meaningful representation of (inter)action regardless of the verifiability of the people's claims and their "real" thoughts.

In the second stage of analysis, I applied approaches inspired by Michel Foucault, notably the sociology of knowledge approach to discourse analysis (Keller 
2012). This approach highlights conditional and socially constructed knowledge that constitutes categories of self-aware and problematizable subjectivities, enabling certain forms of (communicative) action to occur in new socio-spatial circumstances instead of different ones. In the contexts of mediated communications in Yle news reports and on Russian.fi, the interrelated membership subjectivities of Russianness and Finnishness formed constitutive limitations for the ways that people addressed the issue of dual citizenship to their presumed audience. These media platforms and speaker positions are considerably different in their ability to enable people to claim, present, enforce, or challenge common knowledge and ways to interpret phenomena. The critical lens towards knowledge and power concerns the claims of inevitable truths and implied common knowledge, but it also considers normative statements of proper or normal order of things. This approach does not concern the thoughts, intentions, and motivations of people who make statements, nor their verifiability, unless they are questioned by other informants. Hence, I chose to examine archived data of actions and reactions to the dual citizenship news instead of asking informants about these issues directly.

\section{THE NEWS COVERAGE OF DISCRIMINATION}

On January 31, 2017, Finnish national broadcast agency Yle published an online news article in which anonymous whistleblowers from the Finnish Defense Forces claimed that there were unofficial instructions to-illegally exclude-Finnish-Russian dual citizens when recruiting professional soldiers and assigning conscripts to specialization duties. According to the article, the instructions were related to Russia's military activity in Ukraine and consequent deterioration of its relations with the EU (Yle Novosti 2017). Accusing Yle of provocative reporting, the defense minister denied the accusation immediately after the article's publication, but in the following days more discrimination accusations against the defense forces and the Ministry of Foreign Affairs appeared in the media (Teittinen 2017). The National Bureau of Investigation opened an inquiry into two of these accusations and the defense forces conducted their own internal investigation of the subject (Pääesikunta 2017). Yle articles and their presentation on TV (Yle News 2017d) attracted the public's attention and initiated public discussions of the topic. Several news portals in Finland referred to the first Yle article, whereas a few Russian news portals copied its translation from the Yle's Russian-language portal (see Yle Novosti 2017). Before advancing to the analysis of one of the Russian speakers' online discussions in Finland, in this section I first examine how citizenship-membership was represented in the ways in which the journalists and the defense minister portrayed the issue of dual citizenship to Yle's audience.

Citizenship-membership representations produced by Yle journalists were driven more by pragmatism and the letter of the law. Accordingly, citizenship was presented as a legislative instrument that is subjugated to the demands of the changing political and security environment, in this case the relationship with Russia. However, Yle highlighted the obligation of the defense forces to follow Finnish legislation 
and international agreements, regardless of their own preferences. This reasoning departs from establishing citizenship as a constitutional sovereignty above ordinary political decision-making. Yle's articles highlighted the specifics of the Russian citizenship, underlining the nationally, territorially, and temporally varying meaning of being a citizen. The emotional dimension of citizenship-membership was presented in Yle's article dated February 9, 2017, presenting a woman who was denied a position in a barracks kitchen because of her Russian dual citizenship. The article emphasized how being treated unequally compared to other co-citizens may produce a devastating emotional distress and make a dual citizen conclude that she is considered a security threat (Yle News 2017b).

On January 31, the day the first Yle article about discrimination guidelines and practices in the defense forces appeared, the Defense Minister Niinistö denied the existence of such guidelines but stated that the ministry was working on a bill that would disqualify dual citizens from working in the defense forces:

I personally take the view that when we talk about professional military positions, there are weighty reasons excluding dual nationality. There will now be a review to clarify this. The required proposals will be prepared for legislation on the Defence Forces on how national security can be improved in filling professional military positions, and when an individual applies for training leading to a professional officer's commission. (Yle News 2017a)

At this early stage, the minister rationalized the initiative only briefly, presenting it as self-evident and framing it as an urgent matter of national security. In his interview on February 9, Jussi Niinistö defended the restrictions by stating that most Finns seem to agree that the current situation was strange $\mathrm{e}^{1}$ and it may cause dual citizens to face loyalty conflicts and in the worst-case scenario exposes them and their families to blackmail (Pantsu 2017). Accordingly, family ties with people who are subject to another country's law present a considerable liability risk for national defense. This argumentation logic intertwines citizen's relationships of family and national security by subjugating the former under the protection of the latter. Consequently, affiliations abroad undermine the possibility to be a fully entitled citizen. In this relation, Jussi Niinistö admitted that there were some issues with making the suggested dual citizen restrictions compatible with the constitutional provisions of equal citizenship (Pantsu 2017). Here the ideal of citizens' equality appears to be of secondary importance behind national security, which is supported by majority of Finns. In addition, the minister referred to bilateral agreements and regulations that forbid Finland to forward certain intelligence information to citizens of countries not involved in these agreements, which is problematic when it comes to dual citizens (Pantsu 2017). These international agreements, geopolitical relations,

${ }^{1}$ According to a survey conducted on February 2-3, $2017(N=1,050), 66$ percent of respondents supported restrictions on Finnish and Russian dual citizens to work in offices related to national security (Yle News 2017c). 
and national security constitute knowledge that produces equal and reciprocal order between sovereign states, while limiting citizen equality.

Defense Minister Niinistö was arguably the public face of the apologists for restrictions for dual citizens in strategic offices during his term but especially in the period of January-February 2017, when Russian language forums actively discussed the subject. However, the idea to restrict dual citizens' access to certain offices follows complicated processes that involve many other people and organizations. Already in 2003, when the parliament decided to annul the restrictions on foreign citizenships, representatives of the defense forces opposed the decision (Yle News 2003). Also, prior to Jussi Niinistö's term as defense minister, the previous government started to investigate the issue at President Sauli Niinistö's initiative (Yle News 2014a). In 2015, the new government included in its official program an objective to solidify legislation on dual citizenship. Moreover, Jussi Niinistö's party at the time, the nationalist, populist True Finns, officially advocated making the criteria of Finnish citizenship more exclusive (Perussuomalaiset 2013:5-6).

Disagreement between Yle journalists and the defense minister about dual citizenship in the defense forces as an issue of public deliberation roughly reflects the expected respective positions of the media and state security organs towards publicity and Russianness. The Yle journalists suggested that because of the current developments in international affairs, Russia-related concerns were clearly behind the changes in Finnish policies. They presented similar reasoning in 2014 when reporting about the investigation into dual citizenship policies (e.g., Yle News 2014b). First, the defense minister presented the issue as a nationally neutral standardization practice in the matters of international security, downplaying the Russian aspect and casting it as a media spin. Later, he referred vaguely to developments in Russia's legislation as a general international trend to which Finland needs to adapt (Niinistö 2017). Overall, the subjugation of the virtues of social belonging under state security connects the citizenship-membership-related knowledge production by both the defense minister and the Yle journalists. These media presentations constitute much of the basis for considerably less heard but much more inclusive public discussions on online platforms.

\section{RUSSIAN-LANGUAGE DISUSSIONS}

On Russian.fi, the discussion thread about the news of alleged discrimination of dual citizens in the Finnish Defense Forces expanded far beyond the question of who should be eligible to serve in the national defense forces. The first 180 messages fell into several subtopics, including why Russian citizens were spotlighted in the news; what dual-citizenship policies are common around the world; what the negative publicity entails for Russian speakers; and whether the developments could eventually undermine people's (economic and social) everyday security in Finland, in Russia, and globally. From this many-sided and often scattered discussion, I detected discursive citizenship-membership in the representation and problematization of entitlement, the quality of affection of the citizen-state bond, socio-environmental inte- 
gration, and primordiality in "proper" membership norms. This section is structured around these four aspects, but the structure also reflects the scattered form and quality of discussion.

\section{EARNED ENTITLEMENT}

One of the core questions about membership inclusion/exclusion raised in the thread on the dual citizenship news was entitlement. Generally, the collective "we" of the forum referred to a group of Finland's Russian speakers, many, but not all, of whom were believed to represent Finnish-Russian dual citizens. The collective "we" emerged as a salient issue of qualified entitlement of citizenship-membership and led to a deeper discussion about whether issues related to dual citizenship are "ours" to be concerned with.

In the following set of messages the first writer criticizes the indifference of previous commentators regarding their own rights as Finnish citizens. The message implies a normatively productive idea that proper Finnish citizenship-membership, which citizens should strive for, entails active and empowering societal subjectivity, whereas aversive citizen subjectivity is passive and disengaged:

It is strange how people limit their own rights even in a country that they are citizens of. Apparently, they themselves do not quite feel as citizens of Finland. (Discussion participant 1)

I'll ask again... Why did YOU get so agitated on this thread? You have two citizenships and they don't accept you as generals in the Finnish military?-Those who follow this forum are unemployed and do not plan to serve as generals or in Finland's special forces. (Discussion participant 2)

Criticizing the position of the previous message, the writer of the second message downplays news reports about dual citizenship restrictions as a problem that does not concern the average forum participant. The message questions the authority and entitlement of the active members of Russian.fi to have a say in defining what qualifications are required for the Finnish military offices. Like the previous writer, discussion participant 2 also understands an entitled citizenship-membership as something to be earned. However, instead of civic and political activism, the latter citizenship-membership resonates more with what Jakobson (2017) interpreted as the discursive legacy of Soviet citizenship among immigrants from Estonia. Similarly, several people in the discussion tread underlined virtues of providing for themselves without relying on social welfare, of paying taxes, and, at times, completing military service.

\section{SITUATED PRAGMATISM AND AFFECTION}

From interviews with Finland's Russian speakers, Eveliina Heino and Minna Veistilä (2015) infer how employment is considered both as an instrument of gaining social networks and integration and as a primary goal. In the Russian.fi thread, however, several arguments juxtaposed the people who want to acquire citizenship for social integration and the people who want it to improve their career prospects. The prag- 
matist position viewed citizenship as an instrumental commodity that entails economic (work, ownership, pension) and spatial (mobility and residence) rights and value. This was portrayed as a normatively "genuine" citizenship through its rationality for individual and as a global historical trend. The idea of citizenship as an affective membership, on the other hand, emphasized social reflexivity and affections, claiming normative genuineness by being a matter of "heart." The dimensions of social integration and belonging were particularly highlighted in this idea of affective membership, but the pragmatist position also implied their relevance. Several self-proclaimed pragmatic (or "nonideological") citizens referred to their work affiliation as something that entails authority as an expert in their country of residence, regardless of their emotional attachment.

Authors of some of the messages highlighted the importance of emotional attachment and expressed readiness to accept limitations in membership entitlement for dual citizens, even if it includes themselves. While the following three messages manifest different positions towards accepting instrumental relationship to citizenship, they all juxtapose it with the membership ideals of collective affection:

It all depends. I personally feel Russian; it would be silly to think that I am a Finn just because of the passport :-). But it is convenient to have both [passports] in this case. (Discussion participant 3)

We're not saying that one shouldn't have a career in the army. In the end, only few are interested.-If a person took the oath, then it doesn't matter how many citizenships he has. He swore to protect the interests of Finland. If he breaks it-court trial, prison. The rest is the defense minister's paranoia. (Discussion participant 4)

I could've become a Finnish citizen three times already, but I don't need it, because I think that exchanging citizenship only for local "goods" is a sin. Being a citizen of a country, it is also a responsibility: political, moral. (Discussion participant 5)

The second message discusses the readiness to sacrifice oneself for the community, highlighting the individual's choice of which national interests to serve and downplaying the idea that membership automatically entails collective loyalty. Emphasizing the moral dimension of citizenship-membership, the third message presents the ideal citizenship-membership as a collective moral obligation. The author claims that he does not apply for the Finnish citizenship out of principle, despite losing its instrumental benefits. Unfortunately, the opposing positions towards the individuality of members' collective commitments interacted at a rather superficial level in the thread, without development of a deep dialogue between them. This shortcoming is arguably partially influenced by the online forum as a medium of communication.

\section{INTEGRATIVE ENVIRONMENT}

Jürgen Gerdes and Thomas Faist (2007:146) note that the principle of integration before becoming a citizen is popular among political actors opposing dual citizen- 
ship in immigrant-receiving countries. While many people in the Russian.fi discussion approved naturalization without affectual integration, the requirement to integrate socially into the state of residence informally as well as formally in order to become a proper member of the society was barely questioned. In this discourse, there is certain acceptance of inequality among citizens, which is based on how well they are socially integrated through experience and cultural knowledge:

Who is talking about discrimination? How long have you been Finnish citizens yourselves? What is Finnish in you besides the passport and a rather poor knowledge of the Finnish language? $95 \%$ of those who moved from the former USSR in their conscious age are people raised in the Soviet-Russian mentality, not having anything in common with the Western one (except, of course, common Christian values). You only need the passport as a guarantee to stay here. And now the one who thinks he is a true Finn shall throw the first stone. (Discussion participant 6)

I'll tell you a story. A Finnish woman asked me how long I had been here. 24 years I say. She answers: “0h, I hadn't been living here for 18 years. I've been back now for half a year. I can't imagine how people live here." I think this is quite an indicator. Well, people live, and I live like at home. (Discussion participant 7)

Although the Russian.fi participants often make the distinction between "Finns" and "we," the second writer responds to the previous message by telling how, through years of integration, Finland has become more of a home to her than it is to some people who are born there. These statements highlight the idea of growing into, and possibly out of, citizenship-memberships.

The role of public institutions in constituting a nation is well established (Foucault [1975] 1995; Anderson 1983; Triadafilopoulos 2007), and in a similar way many Russian.fi participants connected the experience in school and military service to belonging and citizenship-membership. The following messages highlight symbolic meaning of conscription for national belonging, pride, recognition, and exclusion. The first writer issues a concern about how through notable national publicity and existing stigmas the news about the exclusion of Finnish-Russian dual citizens from the defense forces indirectly undermines general reputation of all people associated with Russia and alienates them as outsiders. While several people in the discussion problematized each other's national belonging and membership, this message reflects a stronger belief in the entitled belonging of their young relatives who have grown up in Finland:

I do not understand this one thing why was this decision taken to make things public in the headlines of newspapers and radio news? Why would you rock the boat for your own citizens? Now, how our 18-year-olds, who have become complete Finns and are going to the army, are going to feel? (Discussion participant 9)

Well, it would be nicer to know that soldiers in Finland are actually "ours," but, damn it, what if they are not. (Discussion participant 10) 
It is permitted to die for the independence of Suomi [Finland, Fin], but not to know secrets and climb the career ladder to the same level as Finns. Such second-grade "cannon fodder." (Discussion participant 11)

Regarding the question of troops, citizenship type does not matter. It has been clear for a long time that they take anyone for "cannon fodder," but for the strategic forces (antiaircraft defense, air force), they prefer their "own." (Discussion participant 12)

Downplaying the "patriotic glory," the last two messages are examples of critique of the belief that people can become proper members of the Finnish nation through conscription. The inclusive naturalization of citizens is suggested to be a ploy to raise enough disposable soldiers, separated from the "full-fledged Finns" who get the most important, prestigious, and protected military positions. Also challenging the integrative role of army, few claimed that patriotic "loyalty" fails to reach the "hearts" of contemporary youth who lack the will to sacrifice themselves for their country. Accordingly, state-citizen relationship in contemporary world was understood increasingly opportunistically and instrumentally.

\section{BORN TO FINNISHNESS?}

A notable part of the discussion about citizenship instrumentality was speculations about whether renouncing their second citizenship would make people de facto socially accepted and fully eligible to serve in offices reserved for Finnish citizens. This raised the question of whether it is possible to become accepted (as a Finn) regardless of foreign (Russian) parents or place of birth and whether the place of birth and its documentation are deterministic for complete membership or not. This reveals a fatalistic discourse that data about people's family and residence history determines their possibility to be a fully entitled citizen.

Rather than reflecting on their own personal and collective self-perceptions, many of the discussion participants problematized citizenship-membership in relation to the external recognition from Finnish society. People were especially worried about whether officials and human resources personnel may access their background information about foreign affiliations, such as citizenship, residence history, and family history, and use it against them. This concern often coincided with the idea that a naturalized citizenship is primarily instrumental without integrative value, as the following messages suggest:

I also support the idea of citizenship by birth. And all the rest, like "acquired" by various means are sham. So, I consider the rejection of a "birth" citizenship to get a new one as nonsense. However, as I already wrote, this is not the people's problem (they're looking for a better life), but of politicians and their thoughtless laws. (Discussion participant 13)

Seriously speaking, why is a child born here given a Russian citizenship? Just for visa-free travels to Russia? Is it worth it to become "a half-breed"? And who did this, whether the parents or ... made the child a half-breed due to their totally incomprehensible personal goals... (Discussion participant 14) 
Regarding the reason not to take foreigners to military institutions: it is irrelevant whether you have Finnish citizenship or not... They will exclude you even with it. There is easily accessible information about your birthplace and parents, not just for the institutions of national defense. (Discussion participant 15)

The statements about parents doing their children a disfavor when giving them dual citizenship and references to them as "half-breeds" demonstrate and reproduce the idea that people are inherently disempowered outside of their ethnic nationstates. The third commentator notes the possibility that all personal and family history data are used for social and political exclusion. The discussion of personal data reflected concerns and beliefs that Finns do not completely trust or accept as their equals people who do not fulfill the generational (primordial) or ethnic membership criterion.

While some characterized ethnic favoritism as a universal practice, surprisingly few addressed the aspects of national particularity of exclusion. A brief subtopic about whether limitations apply to all dual citizens or only to Russians demonstrates that some accepted inequality between dual citizens and holders of a single citizenship if Russians were not treated as an exception. Specifically, people were interested in whether Russian citizens had legal status equal to the US citizens'. However, a few claimed that they should be more compatible with Finnishness than immigrants from other religions, backgrounds, or countries of origin (see also Krivonos 2019). In another subtopic, a commentator questioned the plan of some dual citizens to return to their "home country," claiming that living abroad labels them as traitors in Russia. This refers to the notion that a decision to move away from one's native country is antipatriotic (see Goode 2016:442; Oivo and Davydova-Minguet 2019). Overall, the discussion on Russian.fi illustrated how transnational identity may at its worst be seen as an irreversible and alienating burden for their holders, even as something inherited from their birth. However, there were also people who, without antagonism, referred affectionately to their dual citizenship-membership as an entitled generational heritage: "Choosing between my mother and my father is way over my head" (Discussion participant 16).

\section{DISCUSSION AND CONCLUSIONS}

Inspired by Georgiou (2013:96) and Heino (2018:75), I have examined contextually novel, ICT-enabled representations of citizenship from the perspective of not only established and visible public authorities but also the people who are subjectified by this knowledge production. Examining presentations of citizenship as a discursive citizenship-membership provides a critical perspective on how social construction of affiliated belonging is problematized under certain conditions. In the first part of my analysis, I have shown how from their institutionally strong positions as producers of common knowledge, both the minister of defense and Yle journalists represented citizenship rather narrowly as a legal-political instrument that has flexibility to make exceptions when international (security) environment so demands. This revealed a 
similarity between the two positions, despite their divergent representation of Russia in the constitution of Finland's discursive environment.

My findings from observations of how the citizenship is problematized in an online forum of Finland's Russian speakers highlight the relevance of everyday and practical meanings related to work, integration, and reputation among the rest of the population. Implying both distanced formality and elements of people's identification with their physical and social environments, these discussions resonated with Jakobson's (2017) findings of the Soviet legacy and transnationalism embedded in the citizenship relations of Estonians in Finland.

I gradually recognized from the forum thread that the discussions manifested implicit acceptance of and even support for the initiative to impose restrictions on dual citizens more than was initially apparent. Even explicitly, many argued that Finnish citizenship should not be a (fully) equalizing asset due to the significantly different reasons people have it. Some participants argued that such fully entitled citizenship-membership should be earned through experience and recognition from other Finns, whereas others emphasized the primacy of a citizen's own feeling of belonging. The belief that membership recognition is determined by people's personal (family) history data produced ideas of powerlessness and alienation from the rest of Finnish society. This can be connected to the news that government officials wanted to make personal data available to determine eligibility of their candidates. The acceptance of the idea that citizens are not equal in their membership manifested also in the lack of statements urging to "correct" the people who do not exhibit the behavior of full members.

Considering that online discussion forums generally help people to overcome state borders in their social encounters and create ways to comprehend the world, it was somewhat surprising that the liberal citizenship-membership discourse appeared to be weak in online discussions. This weakness arguably manifests effectiveness of the long-term construction of exclusive Russian and Finnish citizenshipmembership (Ronkainen 2006; Lohr 2012). Previous studies support the conclusion that the socially dominant discourse about an ethnic or primordial Finnishness enhances (not forces) the inability to fully belong to the Finnish citizenship-membership (Davydova 2009; Mähönen et al. 2015; Simonsen 2017). Since the online forum generally did not generate thorough and coherent discussion between opposing points of view, possibilities for its analysis were limited. Hence, I recommend considering a different kind of medium for relevant research in the future.

In previous interview-based studies of people with Russian background, participants perceived "immigration" as a period of crisis, an in-betweenness and external nonrecognition. Moving on from this phase requires the experience of being able to control their own everyday lives (Heino 2018:71-73). Hence, people with immigration background may perceive authorities questioning their citizenship entitlement as degrading their established belonging, integration, and recognition and return to the state of insecurity of an "immigrant." Thereofre, it is easy to understand complaints of the people on Russian.fi who believe that it is possible for them to become recognized members of Finnish society. 
The online discussion revealed grievances about the ambiguity of Finnish citizenship-membership from the perspective of a group of Finland's Russian speakers in early 2017. Dealing with citizenship as an ad hoc negotiable legal instrument of foreign politics provides national governments with leeway to protect their strategic and decision-making institutions. This, however, is not effective for normative subjectification of citizens as ideal members of the society. My research suggests that state policies constructing citizenship as a loosely instrumental membership can undermine people's sense of belonging and, possibly, their commitment to civil society and trust in the state as a guarantor of structural stability of their lives.

\section{REFERENCES}

Anderson, Benedict. 1983. Imagined Communities: Reflections on the Origin and Spread of Nationalism. London: Verso.

Atkins, Robert, and Daniel Hart. 2003. "Neighborhoods, Adults, and the Development of Civic Identity in Urban Youth." Applied Developmental Science 7(3):156-164. https://doi.org/10.1207 /S1532480XADS0703_6.

Bauböck, Rainer. 2019. “Genuine Links and Useful Passports: Evaluating Strategic Uses of Citizenship." Journal of Ethnic and Migration Studies 45(6):1015-1026. https://doi.org/10.1080/13 69183X.2018.1440495.

Blatter, Joachim. 2011. "Dual Citizenship and Theories of Democracy." Citizenship Studies 15(67):769-798. https://doi.org/10.1080/13621025.2011.600090.

Brubaker, Roger. 1992. Citizenship and Nationhood in France and in Germany. Cambridge, MA: Harvard University Press.

Davydova, Olga. 2009. "Suomalaisena, venäläisenä ja kolmantena: Etnisyysdiskursseja transnationaalissa tilassa." PhD dissertation, University of Joensuu.

Davydova-Minguet, Olga. 2017. "Suomen venäjänkielinen media ja monietninen julkisuus." Idäntutkimus 3:3-19.

Davydova-Minguet, Olga, Tiina Sotkasiira, Teemu Oivo, and Janne Riiheläinen. 2016. "Suomen venäjänkieliset mediankäyttäjinä." Valtioneuvoston selvitys- ja tutkimustoiminnan julkaisusarja 35. https://tietokayttoon.fi/julkaisu?pubid=14701.

Faist, Thomas. 2007. "Introduction: The Shifting Boundaries of the Political." Pp. 1-23 in Dual Citizenship in Global Perspective: From Unitary to Multiple Citizenship, ed. by Thomas Faist and Peter Kivisto. New York: Palgrave Macmillan.

Floridi, Luciano, ed. 2015. The Onlife Manifesto: Being Human in a Hyperconnected Era. Cham, Switzerland: Springer Open.

Forsander, Annika, and Elina Ekholm. 2001. "Etniset ryhmät Suomessa." Pp. 57-82 in Monietnisyys, yhteiskunta ja työ, ed. by Annika Forsander, Elina Ekholm, and Petri Hautaniemi. Helsinki: Palmenia-kustannus.

Foucault, Michel. [1975] 1995. Discipline and Punish: The Birth of Prison. New York: Vintage Books.

Georgiou, Myria. 2013. "Diaspora in the Digital Era: Minorities and Media Representation." Journal on Ethnopolitics and Minority Issues in Europe 12(4):80-99.

Georgiou, Myria, and Roger Silverstone. 2007. "Diasporas and Contra-Flows beyond Nation-Centrism." Pp. 30-43 in Media on the Move: Global Flow and Contra-Flow, ed. by Daya Kishnan Thussu. London: Routledge.

Gerdes, Jürgen, and Thomas Faist. 2007. "Varying Views on Democracy, Rights and Duties, and Membership: The Politics of Dual Citizenship in European Immigration States." Pp. 135-158 in Dual Citizenship in Global Perspective: From Unitary to Multiple Citizenship, ed. by Thomas Faist and Peter Kivisto. New York: Palgrave Macmillan.

Goode, J. Paul. 2016. "Love for the Motherland." Russian Politics 1(4):418-449. https://doi.org /10.1163/2451-8921-00104005. 
Heino, Eveliina. 2018. “Yhteiskunnan Jäsenyyden Ehdot: Arjen kansalaisuuden rakentaminen ja peruspalvelukokemukset venäläistaustaisten perheiden kertomuksissa." PhD dissertation, Faculty of Social Sciences, University of Helsinki.

Heino Eveliina, and Minna Veistilä. 2015. “Integration, Recognition and Security: Discourses on Social Support by Families of Russian Background Living in Finland." Nordic Journal of Migration Research 5(2):91-98. https://doi.org/10.1515/njmr-2015-0013.

Husa, Jaakko, and Teuvo Pohjalainen. 2008. Julkisen vallan oikeudelliset perusteet: Johdatus julkisoikeuteen. Helsinki: Talentum.

Jakobson, Mari-Liis. 2017. “'It All Does Not Matter That Much in the European Union': Migrant Transnationalism and the Transformation of Post-Communist Citizenship Discourse." Europe-Asia Studies 69(5):754-770. https://doi.org/10.1080/09668136.2017.1340435.

Keller, Reiner. 2012. “Entering Discourses: A New Agenda for Qualitative Research and Sociology of Knowledge." Qualitative Sociology Review 8(2):46-75.

Kinnvall, Catarina. 2004. "Globalization and Religious Nationalism: Self, Identity, and the Search for Ontological Security." Political Psychology 25(5):741-767.

Kissau, Kathrin, and Uwe Hunger. 2010. "The Internet as a Means of Studying Transnationalism and Diaspora." Pp. 245-265 in Diaspora and Transnationalism: Concepts, Theories and Methods, ed. by Rainer Bauböck and Thomas Faist. Amsterdam: Amsterdam University Press.

Kozinets, Robert V. 2012. Netnography: Doing Ethnographic Research Online. Los Angeles: SAGE.

Krivonos, Daria. 2019. "Migrations of the Edge of Whiteness: Young Russian-Speaking Migrants in Helsinki, Finland." PhD dissertation, Faculty of Social Sciences, University of Helsinki.

Lohr, Eric. 2012. Russian Citizenship: From Empire to Soviet Union. Cambridge, MA: Harvard University Press.

Mähönen, Tuuli Anna, Sirkku Varjonen, Nicholas Prindiville, Linda Arnold, and Inga Jasinskaja-Lahti. 2015. "Boundaries of National Belonging in Ingrian Finnish Return Migration: A MultiLevel Perspective." Nordic Journal of Migration Research 5(3):126-134. https://doi .org/10.1515/njmr-2015-0018.

Midtbøen, Arnfinn H. 2019. "Dual Citizenship in an Era of Securitisation: The Case of Denmark." Nordic Journal of Migration Research 9(3):293-309. https://doi.org/10.2478/njmr-2019-0014.

Miller, Alexei. 2010. "The Nation as a Framework for Political Life." Russian Social Science Review 51(1):21-42. https://doi.org/10.2753/RUP1061-1940470201.

Neumann, Iver B. 1999. Uses of the Other: The East in European Identity Formation. Manchester, UK: Manchester University Press.

Oivo, Teemu. 2017. “Pelko Pohjois-Karjalan Venäjä-keskustelussa ja uutisoinnissa." Lähde: Historiatieteellinen aikakausikirja 14:82-104.

Oivo, Teemu, and Olga Davydova-Minguet. 2019. "Kaksoiskansalaisuuden turvallistaminen ja Suomen venäjänkieliset." Idäntutkimus 4:59-76. https://doi.org/10.33345/idantutkimus .87292.

Pietiläinen, Jukka. 2016. "Venäläisvähemmistö Suomen mediassa." Pp. 140-152 in Venäjänkieliset Suomessa, ed. by Arno Tanner and Ismo Söderling. Turku, Finland: Painosalama.

Ronkainen, Jussi. 2006. "Monikansalaisuus ja monimuotoistuva suomalaisuus." Pp. 237-256 in Ylirajainen kulttuuri: Etnisyys Suomessa 2000-luvulla, ed. by Tuomas Martikainen. Helsinki: Hakapaino.

Ronkainen, Jussi. 2009. “Väliviivakansalaiset: Monikansalaisuus asemana ja käytäntönä.” PhD dissertation, University of Joensuu.

Ronkainen, Jussi. 2011. “Mononationals, Hyphenationals, and Shadow-Nationals: Multiple Citizenship as Practice." Citizenship Studies 15(2):247-263. https://doi.org/10.1080/13621025.201 1.549723.

Seppänen, Janne, and Esa Väliverronen. 2012. Mediayhteiskunta. Tampere, Finland: Vastapaino.

Simonsen, Kristina B. 2017. “Does Citizenship Always Further Immigrants' Feeling of Belonging to the Host Nation? A Study of Policies and Public Attitudes in 14 Western Democracies." Comparative Migration Studies 5(1):1-17. https://doi.org/10.1186/s40878-017-0050-6. 
Triadafilopoulos, Triadafilos. 2007. "Dual Citizenship and Security Norms in Historical Perspective." Pp. 27-41 in Dual Citizenship in Global Perspective: From Unitary to Multiple Citizenship, ed. by Thomas Faist and Peter Kivisto. New York: Palgrave Macmillan.

Van Waas, Laura, and Sangita Jaghai. 2018. "All Citizens Are Created Equal, but Some Are More Equal Than Others." Netherlands International Law Review 65:413-430. https://doi.org/10.1007 /s40802-018-0123-8.

Varjonen, Sirkku, Linda Arnold, and Inga Jasinskaja-Lahti. 2013. “'We're Finns Here, and Russians There': A Longitudinal Study on Ethnic Identity Construction in the Context of Ethnic Migration." Discourse \& Society 24(1):110-134. https://doi.org/10.1177/0957926512463632.

Varjonen Sirkku, Aleksandr Zamiatin, and Marina Rinas. 2017. Suomen venäjänkieliset: tässä ja nyt. Tilastot, tutkimukset, järjestökentän kartoitus. Turku, Finland: Painosalama.

Yuval-Davis, Nira. 2006. "Belonging and the Politics of Belonging." Patterns of Prejudice 40(3):197214. https://doi.org/10.1080/00313220600769331.

\section{SOURCES}

Eduskunta.fi. 2019. “Eduskunnan vastaus EV 280/2018 vp." Eduskunta, March 5. https://www .eduskunta.fi/FI/vaski/EduskunnanVastaus/Documents/EV_280+2018.pdf.

Finnish Immigration Service. N.d. “Finnish Citizenship." Accessed July 24, 2020. https://migri.fi /en/finnish-citizenship.

Mentula Aapo, and Aleksi Teivanen. 2014. “New Dual Citizenship Regulations a Concern for Russians in Finland." Helsinki Times, August 20. https://www.helsinkitimes.fi/finland/finland-news /domestic/11648-new-dual-citizenship-regulations-a-concern-for-russians-in-finland.html.

Ministry of the Interior. 2017. International Migration 2016-2017: Report for Finland. http:// julkaisut.valtioneuvosto.fi/bitstream/handle/10024/160257/SM_28_2017.pdf.

Niinistö, Jussi. 2017. “Kaksoiskansalaisuus ja puolustusvoimat." Jussi Niinisto (blog), February 8. https://web.archive.org/web/20170209181203/http://jussiniinisto.fi/index.php/2017/02 /kaksoiskansalaisuus-ja-puolustusvoimat/.

Pääesikunta. 2017. “Puolustusvoimat selvitti kaksoiskansalaisuuteen liittyvät käytännöt." Puolustusvoimat, February 8. https://puolustusvoimat.fi/artikkeli/-/asset_publisher/puolustusvoimat-selvitti-kaksoiskansalaisuuteen-liittyvat-kaytannot?_101_INSTANCE_j06rL1egTPfP_ languageId=fi_FI.

Pantsu, Pekka. 2017. “Niinistö: Väitettä tiedustelulaitoksesta selvitettävä-'Olen melko vakuuttunut, ettei se ole voinut antaa virallista ohjeistusta."' Yle, February 9. https://yle.fi /uutiset/3-9450787.

Perussuomalaiset. 2013. Perussuomalaisten maahanmuuttopoliittinen ohjelma 2015. https://www .perussuomalaiset.fi/wp-content/uploads/2013/04/Maahanmuuttopoliittinen.pdf.

Schwartz, Leena, Evgeniia Kriuchkova, and Alla Nesterovich. 2018. "Helsingin Sanomille: Aloite vihaa lietsovien kuvien poistamisesta ja julkisen anteeksipyynnön esittämisestä." Adressit.fi, December 10. https://www.adressit.com/helsingin_sanomille_aloite_vihaa_lietsovien _kuvien_poistamisesta_ja_julkisen_anteeksipyynnon_esittamisesta.

Teittinen, Paavo. 2017. “Ulkoministeriön turvallisuusjohtaja: Monelle Venäjän kaksoiskansalaiselle ei anneta pääsyä arkaluontoisiin tietoihin." Helsingin Sanomat, February 3. https://www .hs.fi/paivanlehti/03022017/art-2000005072374.html.

Valtiovarainministeriö. 2017. "Valtion virkamieslain ja turvallisuusselvityslain muutokset voimaan 1.1.18." December 19. https://vm.fi/-/valtion-virkamieslain-ja-turvallisuusselvityslain -muutokset-voimaan-1-1-2018.

Vasutin, Ruslan. 2014. “New Regulations on Dual Citizenship in Russia." Lexology, June 11. https:// www.lexology.com/library/detail.aspx?g=0069ea18-6324-4d7e-9409-dc30e9af471c.

Yle News. 2003. “Dual Citizenship Law Sparks Criticism.” February 4. https://yle.fi/uutiset/3-5126799.

Yle News. 2014a. "President: It Was Me Who Ordered Dual-Citizenship Rethink." August 22. https://yle .fi/uutiset/osasto/news/president_it_was_me_who_ordered_dual-citizenship_rethink/7426339. 
Yle News. 2014b. “Räsänen Explores Possibility of Scrapping Dual Citizenship.” August 22. https:// yle.fi/uutiset/osasto/news/rasanen_explores_possibility_of_scrapping_dual_citizenship /7425764.

Yle News. 2017a. “Defence Minister: Weighty Reasons to Close Professional Military Positions to Dual Nationals." January 31. https://yle.fi/uutiset/osasto/news/defence_minister_weighty _reasons_to_close_professional_military_positions_to_dual_nationals/9434718.

Yle News. 2017b. “Dual Finnish-Russian Citizen Denied Work at Garrison Kitchens." February 9. https://yle.fi/uutiset/osasto/news/dual_finnish-russian_citizen_denied_work_at_garrison _kitchens/9452206.

Yle News. 2017c. "Survey: Half of Finns See Finnish-Russian Dual Citizens in the Defence Force as a Serious Threat." February 3. https://yle.fi/uutiset/osasto/news/survey_half_of_finns_see_ finnish-russian_dual_citizens_in_the_defence_force_as_a_serious_threat/9441898.

Yle News. 2017d. "Yle Uutisluokka Triplet." Feburary 1. https://areena.yle.fi/1-3968963.

Yle News. 2018. "Proposed Finnish Dual Citizen Law Stricter than in Neighbouring States." February 8. https://yle.fi/uutiset/osasto/news/proposed_finnish_dual_citizen_law_stricter_than_ in_neighbouring_states/1006540756.

Yle Novosti. 2017. “Oboronitel'nye sily vveli osoboe nabliudenie v otnoshenii lits s dvoinym grazhdanstvom Finliandii i Rossii-Takzhe vvedeny ogranicheniia na deiatel'nost' soldat -srochnikov." January 31. https://yle.fi/uutiset/osasto/novosti/oboronitelnye_sily_vveli _osoboe_nablyudenie_v_otnoshenii_lits_s_dvoinym_grazhdanstvom_finlyandii_i_rossii takzhe_vvedeny_ogranicheniya_na_dyeyatelnost_soldat-srochnikov/9433482?origin=rss.

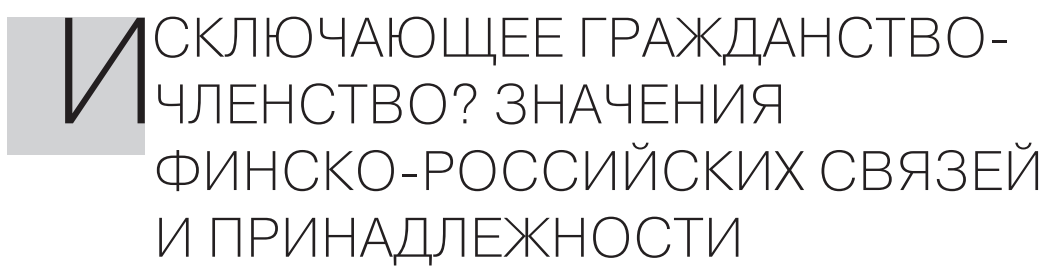

\section{Teeму Ойво}

Теему Ойво, Карельский институт, Университет Восточной Финляндии. Адрес для переписки: University of Eastern Finland, PL 111, Joensuи, 80101, Finland.teemu.oivo@uef.fi.

Помимо определения юридических отношений между человеком и государством, гражданство имеет и менее формальные значения, такие как закрепление принадлежности к сообществу, а также расширение прав и возможностей в социуме. Представления о том, каким должен быть «хороший гражданин», отражают нормативное социально-политическое устройство общества. Одновременно на представления о гражданстве влияние оказывают вопросы прав человека, миграции, безопасности, геополитики и государственного строительства. В Финляндии инициативы по пересмотру ранее либеральной концепции гражданства стали активно обсуждаться в публичном пространстве после изменений в дискурсе европейской безопасности в 2014 году. В начале 2017 года в СМИ появились новости о том, что людям, имеющим двойное финско-российское гражданство, было негласно запрещено занимать стратегически значимые воинские должности. Данная статья анализирует представляемые финскими СМИ новости об изменениях в законодательстве о гражданстве, а 
также спонтанные дискуссии на эту тему на русскоязычном онлайн-форуме в Финляндии. Таким образом, статья исследует дискурсивное отношение людей к гражданству как членству в «финскости» и «русскости». Способы определения, подтверждения и оспаривания «настоящего» гражданства отчетливо различаются в дискурсах СМИ Финляндии и онлайн-дискуссий на русском языке. В СМИ журналисты и министр обороны Финляндии определяли гражданство прежде всего как гибкий инструмент политики в сфере международной безопасности. В то же время в рамках дискуссий на русскоязычном онлайн-форуме были сформулированы представления о возможности принадлежности к гражданству посредством личных достижений и интеграции в социальную среду. Наиболее отчуждающий дискурс повлек за собой веру в то, что документация семейной истории необходима для включения в гражданство-членство. Наименее инклюзивные способы понимания гражданства формировались в рамках дискурса, постулирующего необходимость подтверждения семейной истории и происхождения для включения в сообщество граждан.

Ключевые слова: гражданство; национальная идентификация; онлайн-дискуссия; дискурсивное гражданство; транснационализм 